\title{
CAUSAL ANALYSIS OF RELIGIOUS VIOLENCE, A STRUCTURAL EQUATION MODELING APPROACH $^{1}$
}

\section{Munajat}

State Institute of Islamic Studies (IAIN) Salatiga, Indonesia email:munajatstain@gmail.com

\section{Abstract}

The present study tries to investigate the causal model of religious violence using SEM (Structural Equation Modeling) approach. Previous quantitative research in social movements and political violence suggests that there are, at least, three factors, that caused violent collective actions, including religious violence: 1) the more fundamentalist people are, the more likely they justify violence, 2) people with lower trust in government is more likely to justify violence, and 3) opposing the second argument: only people with low trust in government and high political efficacy are more likely to justify violence. Based on the data of 343 respondents, the activists of Front Pembela Islam, Muhammadiyah and Nabdlatul Ulama, this study confirms that the more fundamentalist people are, the more likely they are to justify violence regardless of their organizational affiliations. On the contrary, this study does not support the argument for the relationship between trust in government and violence. Similarly, the relationship between violence and the latent interaction of trust and political efficacy is not supported by the data. Therefore, this study suggests that fundamentalism, a type of religiosity, is a salient factor to explain religious violence.

Penelitian ini berusaha mengkaji sebab kekerasan keagamaan dengan menggunakan pendekatan Model Persamaan Struktur (SEM). Penelitian

${ }^{1}$ The original version of this article was presented in absentia at the International Research Conference on Mubammadiyah (IRCM) 2012 "Discourse on the Search for a Renewed Identity of Muhammadiyah for its Post-Centennial Era" University of Muhammadiyah Malang (UMM), November 29 - December 2, 2012. 
Munajat

kuantitatif terdahulu dalam bidang gerakan sosial dan kekerasan politik menunjuk.kan bahwa setidaknya ada tiga faktor yang diduga kuat menjadi penyebab kekerasan kolektif, seperti kekerasan agama, yaitu: 1) semakin fundamentalis seseorang, maka ia akan semakin cenderung menyetujui pernggunaan cara kekerasan, 2) semakin rendah kepercayaan seseorang terhadap pemerintah, maka ia akan semakin menyetujui penggunaan kekerasan, 3) berbeda dengan pendapat ke-dua, hanya orang yang rendab kepercayaanya kepada pemerintah, namun mempunyai semangat politik tinggi, yang akan menyetujui penggunaan cara-cara kekerasan. Berdasarkan pada data yang diambil dari 343 responden dari para aktivis, Front Pembela Islam, Mubammadiyah dan Nabdlatul Ulama, penelitian ini mengkonfirmasi bahwa semakin fundamentalis seseorang, maka ia akan semakin cenderung menyetujui kekerasan, terlepas dari afiliasi organisasi mereka. Namun demikian, penelitian ini tidak mendukung bubungan antara kepercayaan terhadap pemerintah dan kekerasan. Demikian juga, bubungan antara kekerasan dan interaksi antara kepercayaan pemerintah dan semangat politik tidak dapat dibuktikan dari data dalam penelitian ini. Oleh karena itu, penelitian ini menyimpulkan bahwa fundamentalisme, sebagai salah satu bentuk keagamaan, merupakan faktoryang sangatpenting dalam menjelaskan kekerasan keagamaan.]

Keywords: fundamentalism, trust in government, political efficacy, religious violence, Structural Equation Modeling

\section{A. Introduction: Examining Religious Violence}

There are various perspectives of looking at political violence, especially religious violence. There is no single answer to the question of why this violence occurs. Several studies look at violence by focusing on the political environments. They suggest that the characteristics of regimes or states are considered to be more determining of social movement's outcomes than other environmental factors, or more over the characteristics of the actors. In this light, authoritarianism or state repression is often considered to be the cause of the emergence of violent movements. A group resorts to violence because the way and the process toward normal pacific competition have been blocked. ${ }^{2}$ Harsh repression blocks moderate tactics and subsequently tends to radicalize

${ }^{2}$ Earl Conteh-Morgan, Collective Political Violence: An Introduction to the Theories and Cases of Violent Conflicts (New York: Routledge, 2004), pp. 14-5. 
the movement and pushes tactics toward violence. ${ }^{3}$

Other studies look at internal or endogenous factors of the movements, such as culture, meaning construction, ideology and other factors that relate to minds and emotions of the movement or actors. For example, many social movement scholars argue that political violence is mainly symbolic. Therefore, in analyzing violence, cultural and emotional effects are more important than the material damage caused by violence. ${ }^{4}$ Juergensmeyer explores the relationship between religion and violence through culture. He argues that violence is a form of public performance symbolizing ability to terrorize the community. Religion plays a role in legitimizing the violence and provides the cosmic war that makes the perpetrators believe that they are conducting a holy mission. Even though religion does not always provides moral justification for violence, this kind of alliance between religion and violence can be found in almost every major religious traditions, such as Christianity, Islam, Judaism, Hindu, Sikh and Buddhism. ${ }^{5}$

Other studies prefer to look at political violence as part of the discourse in society. This is because political violence exists within the discourse. For example, in the case of radicalization of the religious movements in El Salvador, Shortell looks at the process of radicalization through the sermon of Romero. He looks at the techniques of describing and explaining the rhetorical strategies by which meaning is deployed in the struggle against the state. Therefore, religious ideology or discourse in this case is not merely theological but it also represents the process of radicalization of movements in El Salvador. ${ }^{6}$

Based on this brief literature reviews, many studies still ignore the socio-environmental aspects that relate to the characteristics of

3 Timothy Shortell, "Radicalization of Religious Discourse in El Salvador: The Case of Oscar A. Romero”, Sociology of Religion, vol. 62, no. 1 (2001), pp. 87-103. Paul Almeida, Waves of Protest: Popular Struggle in El Salvador, 1925-2005 (Minneapolis: University of Minnesota Press, 2008). Quintan Wiktorowicz, "Introduction: Islamic Activism, a Social Movement Theory", in Islamic Activism, a Social Movement Theory Approach, ed. by Quintan Wiktorowicz (Bloomington Indiana: Indiana University Press, 2004), pp. 1-36. Patricia Steinhoff and Gilda Zwerman, "Introduction to the Special Issue on Political Violence”, Qualitative Sociology, vol. 31, no. 3 (2008), pp. 213-20.

${ }^{4}$ Donatella Della Porta, "Research on Social Movements and Political Violence", Qualitative Sociology, vol. 31, no. 3 (2008), pp. 221-30.

${ }^{5}$ Mark Juergensmeyer, Terror in the Mind of God: The Global Rise of Religious Violence (Berkeley: University of California Press, 2003), pp. 5-18.

${ }^{6}$ Shortell, "Radicalization of Religious Discourse in El Salvador", pp. 87-103. Al-Jāmiah, Vol. 53, No. 2, 2015 M/1437 H 
individuals who perpetrate violence. Therefore, this study focuses on examining individual characteristics of movement's activists that explain the adoption of violent means using a quantitative structural equation modeling approach.

Some of the most challenging arguments in quantitative research are that the way of people perceive their religions and their states or governments affects the movement's outcomes. More specifically, they are fundamentalism, political trust and political efficacy. In addition, there are other characteristics that are often assumed to be the causes of political violence, such as poverty, low level of education and unemployment. However, there is still lack of study that confirms this assumption.

Therefore, this study will only assess the relationships between the variable of political violence and the variables of fundamentalism, trust in government and political efficacy in order to assess the causal model of religious violence. First, fundamentalism may be the most conspicuous factor that is often accused as the source of religious violence; even if the violence does not appear to be religious. Even though some scholars ${ }^{7}$ disagree with this idea, many others still believe that the relationship between fundamentalism and religious violence is real. For example, in Altemeyer and Hunsberger's study, the relationship between fundamentalism and hostility towards homosexuality is quite high, with the correlation coefficient of $.50 .{ }^{8}$ Moaddel and Karanbenich found that the more fundamentalist people are, the more likely they are to be fatalistic and feel insecure. ' Similarly, Rothschild found that among Americans, fundamentalism is associated with greater support for significant military interventions. ${ }^{10}$

Second, in addition to fundamentalism, a number of earlier

${ }^{7}$ Jajang Jahroni, Defending the Majesty of Islam: Indonesia's Front Pembela Islam, 1998-2003 (Chiang May, Thailand: Silkworm Books, 2008); Al-Zastrouw Ng, Gerakan Islam Simbolik: Politik Kepentingan FPI (Yogyakarta: LKiS, 2006).

${ }^{8}$ Bob Altemeyer and Bruce Hunsberger, "Research: A Revised Religious Fundamentalism Scale: The Short and Sweet of It", The International Journal for the Psychology of Religion, vol. 14, no. 1 (2004), pp. 47-54.

9 Mansoor Moaddel and Stuart A. Karabenick, "Religious Fundamentalism Among Young Muslims in Egypt and Saudi Arabia”, Social Forces, vol. 86, no. 4 (2008), pp. 1675-710.

${ }^{10}$ Zachary K. Rothschild, Abdolhossein Abdollahi, and Tom Pyszczynski, "Does Peace Have a Prayer? The Effect of Mortality Salience, Compassionate Values, and Religious Fundamentalism on Hostility toward Out-groups", Journal of Experimental Social Psychology, vol. 45, no. 4 (2009), pp. 816-27. 
studies indicate that political discontent or trust in government and political efficacy are associated with violence and radicalization. Miller and Zimmermann argue that the readiness to engage in violence will depend on the degree of trust in political authority. ${ }^{11}$ Similarly, Gamson distinguishes three types of political activities which are used to influence the state: persuasion, inducement and constraint (physical violence). All of these types relate to the level of trust in government. People who have a high trust in government would be likely to use persuasion; those who have a neutral position towards the government, would be likely to use inducement; and those who have a low trust, would be likely to use constraint or violence. In addition, he adds that those who use violence should also have a high efficacy. ${ }^{12}$

Similar to Gamson, others argue that people with high scores of political efficacy but low scores of trust in government tend to resort to violent political actions. ${ }^{13}$ In contrast, others argue that people with low trust in government and low level of political efficacy are susceptible to radical or revolutionary appeals. ${ }^{14}$ However, these two arguments can be tested at the same time by creating an interaction variable between trust and political efficacy and then looking at the results of those interaction in relations to the dependent variable of violence, as it is done in this study.

Based on the above brief literature reviews, the hypothesized model of religious violence can be formulated as follows:

H1a: The more fundamentalist people are, the more likely they will justify violence. If this is true, then go to $\mathrm{H} 1 \mathrm{~b}$ and $\mathrm{H} 1 \mathrm{c}$.

H1b: The activists of the nonviolent groups (Muhammadiyah and NU) will be less likely to be fundamentalist than those of the violent group (FPI). ${ }^{15}$

11 Arthur H. Miller, "Political Issues and Trust in Government: 1964-1970*”, American Political Science Review, vol. 68, no. 3 (1974), pp. 951-72; Zimmermann Ekkart, Political Violence, Crises, and Revolutions: Theories and Research, vol. 79 (Boston, Mass: G. K. Hall, 1985).

12 William A. Gamson, Power and Discontent (Homewood: Dorsey Press, 1968).

13 Jeffery M. Paige, "Political Orientation and Riot Participation", American Sociological Review, vol. 36, no. 5 (1971), pp. 810-20.

${ }^{14}$ William Kornhauser, The Politics of Mass Society (Glencoe: Free Press, 1959); H. Edward Ransford, "Isolation, Powerlessness, and Violence: A Study of Attitudes and Participation in the Watts Riot", American Journal of Sociology, vol. 73, no. 5 (1968), pp. 581-91.

${ }^{15} \mathrm{H} 1 \mathrm{~b}$ is used to reconfirm $\mathrm{H} 1 \mathrm{a}$. If $\mathrm{H} 1 \mathrm{a}$ is true, then $\mathrm{H} 1 \mathrm{~b}$ is expected to be true. Al-jāmíah, Vol. 53, No. 2, 2015 M/1437 H 
Munajat

H1c: The relationship between fundamentalism and violence will be stronger for the activist of FPI than those of Muhammadiyah and NU. ${ }^{16}$ H1d: The activists of the nonviolent groups (Muhammadiyah and NU) will be less likely to justify violence than those of the violent group (FPI). ${ }^{17}$ H2a: People who have a lower trust in government will be more likely to justify violence. If this is true, then go to $\mathrm{H} 2 \mathrm{c}$.

H2b: People who have a low trust in government but high political efficacy will be likely to justify violence. If this is true then go to $\mathrm{H} 2 \mathrm{c}$ and $\mathrm{H} 2 \mathrm{~d}$. H2c: The activists of Muhammadiyah and NU will be likely to have a higher trust in government than those of FPI. ${ }^{18}$

$\mathrm{H} 2 \mathrm{~d}$ : The activists of Muhammadiyah and NU will be likely to have a lower political efficacy than those of FPI. ${ }^{19}$

\section{B. Measuring and Scaling of the Latent Variables}

\section{Fundamentalism}

Originally the term fundamentalism referred to a group of conservative American Protestants in the early 1900s. They were fundamentalists in the sense that they considered themselves to be the people selected to preserve and protect the fundamentals of Christian faith from the liberal ideas, such as Darwinism and modernism. ${ }^{20}$ More recently, the term fundamentalism has been used to identify a type of religiosity that emphasizes a return to traditional values or a glorious past and an accompanying sense of restoration of religious traditions. Therefore, the term fundamentalism is no longer confined to Christianity. It has been expanded into other religions, not only the Abrahamic religions but also Hinduism and Buddhism. ${ }^{21}$

${ }^{16} \mathrm{H} 1 \mathrm{c}$ is used to reconfirm $\mathrm{H} 1 \mathrm{a}$. If $\mathrm{H} 1 \mathrm{a}$ is true, then $\mathrm{H} 1 \mathrm{c}$ is expected to be true.

${ }^{17} \mathrm{H} 1 \mathrm{~b}$ is used to reconfirm $\mathrm{H} 1 \mathrm{a}$. If $\mathrm{H} 1 \mathrm{a}$ is true, then $\mathrm{H} 1 \mathrm{~b}$ is expected to be true.

${ }^{18} \mathrm{H} 2 \mathrm{c}$ is used to reconfirm $\mathrm{H} 2 \mathrm{a}$ and $\mathrm{H} 2 \mathrm{~b}$. If $\mathrm{H} 2 \mathrm{a}$ and $\mathrm{H} 2 \mathrm{~b}$ are true, then $\mathrm{H} 2 \mathrm{c}$ is expected to be true.

${ }^{19} \mathrm{H} 2 \mathrm{~d}$ is used to reconfirm $\mathrm{H} 2 \mathrm{a}$ and $\mathrm{H} 2 \mathrm{~b}$. If $\mathrm{H} 2 \mathrm{a}$ and $\mathrm{H} 2 \mathrm{~b}$ are true, then $\mathrm{H} 2 \mathrm{~d}$ is expected to be true.

20 Paul D. Numrich, "Fundamentalisms and American Pluralism", Journal of Ecumenical Studies, vol. 42, no. 1 (2007), p. 9.

${ }^{21}$ Martin E. Marty and R. Scott Appleby, "Introduction: A Sacred Cosmos, Scandalous Code, Defiant Society", in Fundamentalisms and Society: Reclaiming the Sciences, the Family, and Education, ed. by Martin E. Marty and R. Scott Appleby (Chicago: University of Chicago Press, 1993), p. 5. 
Scholars have different opinions on the definitions of fundamentalism, or what may constitute fundamentalism. That is may be the source of why scholars have different opinions about the relationship between violence and fundamentalism. Some emphasize their concepts on people's religious beliefs, like the truth of one's religion, the relationship with God and treating religious texts; while others emphasize on the manifestations of people's attitude towards religion. These differences can be seen in how both groups define "fundamentalism" as follows.

First, Altemeyer and Hunsberger focus their concept on religious beliefs. They define fundamentalism as follows:

One set of religious teachings that clearly contains the fundamental, basic, intrinsic, essential, inerrant truth about humanity and deity; that this essential truth is fundamentally opposed by forces of evil which must be vigorously fought; that this truth must be followed today according to the fundamental, unchangeable practices of the past; and those who believe and follow these fundamental teaching have a special relationship with deity. ${ }^{22}$

Second, other scholars define fundamentalism in a broader way, not merely based on the religious beliefs. As Berger argues, fundamentalism should be defined by its cognitive style. Both non fundamentalist and fundamentalist adherents share the same beliefs, but they affirm these beliefs in different ways; the former shows a flexible and moderate manner and the latter exhibits an uptight and militant manner. ${ }^{23}$ Similarly, other scholars define fundamentalism as follows:

An identifiable pattern of religious militancy in which self-styled true believers attempt to arrest the erosion of religious identity by outsiders, fortify the borders of religious community and create viable alternatives to secular structures and processes. ${ }^{24}$

The present study considers that the first definition of fundamentalism, which only considers "belief" factor, is problematic. This study, therefore, uses the second definition of fundamentalism in

${ }^{22}$ Bob Altemeyer and Bruce Hunsberger, "Authoritarianism, Religious Fundamentalism, Quest, and Prejudice", The International Journal for the Psychology of Religion, vol. 2, no. 2 (1992), p. 118.

${ }^{23}$ Rebecca Joyce Frey, Fundamentalism (New York: Facts On File, 2007), p. vi.

${ }^{24}$ Gabriel A. Almond, R. Scott Appleby, and Emmanuel Sivan, Strong Religion: The Rise of Fundamentalism Around The World (Chicago: University of Chicago Press, 2003), p. 17. 


\section{Munajat}

order to develop a scale of fundamentalism. In addition, the second definition of fundamentalism does not ignore the aspect of belief, as can be seen in the following traits of fundamentalist:

- Reactivity means reactive attitudes towards something that is considered as degeneration of a tradition, or protective and defensive attitudes towards religion beliefs. Fundamentalists, therefore, perceive threat of their religion from other religions, ethnic groups, the state, or more liberal groups of the same religion.

- Dualistic thinking means a black-white approach to life. Everything is considered as good or otherwise evil, or pure and contaminated.

- Absolutist interpretation of scripture means strict reading of the holy books, or in some cases, accepted traditions.

- An apocalyptic view means a belief that the sacred texts contain hidden mysteries, including historical secrets, such as the concept of the Messiah and Dajjal (the big impostor).

- Belief in chosenness means that Fundamentalists believe in their own specialness as the defenders of the religion. Even though, most fundamentalist groups consist of only a small number of people compared to the mainstream groups, they tirelessly pursue their goals, opposing what they believe to be the prevailing madness within the religion and within the world today.

- Selective emphasis means that fundamentalists focus only certain parts of their religion traditions, and certain aspects of modernity as their target of attacks.

Other factors, such as separation from the world, charismatic style of leadership, and strict behavior of controls, are other fundamentalist characteristic at the group level. ${ }^{25}$ Therefore, these traits (point 7) are not used to measure fundamentalism in this study, which focuses on the individual level. Implementing the above concept of fundamentalism, the Figure 1 shows items used to measure the level of fundamentalism and their theoretical bases.

\section{Trust in Government}

'Trust in government is about citizens' effective orientation toward, and evaluation of, the government. The scale of trust runs from high trust to low trust (high distrust or cynicism). High trust indicates that the government or public servants meet the expectation of the citizens,

25 Frey, Fundamentalism. 


\section{Figure 1: Indicators (Observed Variables) of Fundamentalism}

\begin{tabular}{|c|c|c|}
\hline Coding & Items/Indicators & $\begin{array}{l}\text { Theoretical } \\
\text { Base }\end{array}$ \\
\hline F1 & $\begin{array}{l}\text { We do not need to re-interpret what is clearly and literally stated } \\
\text { in the al-Quran because it is flawless, for example the verses of } \\
\text { the unequal proportion of inheritance between son and daughter. }\end{array}$ & Absolutism \\
\hline $\mathrm{F} 2$ & $\begin{array}{l}\text { Whenever knowledge/science and al-Quran conflict, science } \\
\text { must be wrong; and we do not need to compromise them. }\end{array}$ & Absolutism \\
\hline F3 & $\begin{array}{l}\text { Currently the activities of Christianization targeting Muslim } \\
\text { in Indonesia have become a serious threat to our Muslim } \\
\text { community. }\end{array}$ & Reactivity \\
\hline F4 & $\begin{array}{l}\text { The Islamic liberal groups, like JIL (Jaringan Islam Liberal) have } \\
\text { gone too far from the real tenets of Islam and potentially harm } \\
\text { the true beliefs of Muslim community of Indonesia. }\end{array}$ & Reactivity \\
\hline F5 & $\begin{array}{l}\text { Muslims of Indonesia is in a state of serious danger because of } \\
\text { the widespread of corruptions, pornography, prostitutions, drugs } \\
\text { and other immoralities }\end{array}$ & Reactivity \\
\hline F6 & $\begin{array}{l}\text { Currently, I feel that I am obliged to do something to protect } \\
\text { Islam/Muslim society from such immorality because many } \\
\text { Muslims tend to ignore such problems. }\end{array}$ & $\begin{array}{l}\text { Feeling being } \\
\text { Chosen }\end{array}$ \\
\hline F7 & $\begin{array}{l}\text { To deal with these problems, the government should prioritize } \\
\text { to solve moral problems rather than other problems because } \\
\text { immorality (the moral problem) is the source of all problems. }\end{array}$ & $\begin{array}{l}\text { Selective } \\
\text { emphasis }\end{array}$ \\
\hline F8 & $\begin{array}{l}\text { According to Islam, a woman cannot be a leader, such as } \\
\text { president, governor and mayor. }\end{array}$ & $\begin{array}{l}\text { Absolutism, } \\
\text { Selective } \\
\text { emphasis }\end{array}$ \\
\hline F9 & According to Islam, a woman cannot be a judge. & $\begin{array}{l}\text { Absolutism, } \\
\text { Selective } \\
\text { emphasis }\end{array}$ \\
\hline F10 & $\begin{array}{l}\text { A Muslim must not vote for female candidates for president } \\
\text { or governor. }\end{array}$ & $\begin{array}{l}\text { Absolutism, } \\
\text { Selective } \\
\text { emphasis }\end{array}$ \\
\hline F11 & $\begin{array}{l}\text { The chronic problems of corruption, pornography and other } \\
\text { widespread of immoralities as well as the continuous natural } \\
\text { disasters in Indonesia are signs about the closeness of the end } \\
\text { of the world. }\end{array}$ & $\begin{array}{l}\text { Apocalyptical } \\
\text { Views }\end{array}$ \\
\hline F12 & $\begin{array}{l}\text { The Quran and the Hadith have already predicted the appearance } \\
\text { of Dajjal (the imposter and damage carrier). I believe that the } \\
\text { president of the USA and the prime minister Israel are the Dajjal. }\end{array}$ & $\begin{array}{l}\text { Apocalyptical } \\
\text { Views }\end{array}$ \\
\hline F13 & $\begin{array}{l}\text { Indonesia is a secular state because its constitution is not based } \\
\text { on a religion (Islam or the Quran and Hadith). }\end{array}$ & Dualistic thinking \\
\hline F14 & $\begin{array}{l}\text { Muslims make up the majority of the Indonesian population. } \\
\text { Therefore, state constitutions should be based on Islamic shariah } \\
\text { (al-Quran and al-Sunnah). }\end{array}$ & Dualistic thinking \\
\hline
\end{tabular}

Note: The answers for these statements use 7 points of the Likert scale ( $1=$ strongly disagree to $7=$ strongly agree); and 7 indicate highest level of fundamentalism. 
Munajat

Figure 2: Indicators (Observed Variables) of Trust in Government

\begin{tabular}{cl}
\hline Coding & \multicolumn{1}{c}{ Items/Indicators } \\
\hline T1 & How much of the time can you trust the SBY Administration? \\
\hline T2 & How much of the time can you trust the Provincial/Local Government? \\
\hline T3 & How much of the time can you trust the Police? \\
\hline T4 & How much of the time can you trust the Courts (Pengadilan)? \\
\hline T5 & $\begin{array}{l}\text { How much of the time can you trust the Prosecutor General } \\
\text { (Kejaksaan)? }\end{array}$ \\
\hline T6 & $\begin{array}{l}\text { How much of the time can you trust the People of Congress/Parliament } \\
\text { (MPR/DPR)? }\end{array}$ \\
$\begin{array}{l}\text { Note: The answer for these questions will be } 1=\text { never } 2=\text { only some of the time } 3 \\
=\text { most of the time } 4=\text { always } 0=\text { don't know. The score of } 1 \text { indicates low trust } \\
\text { in government and } 4 \text { indicates high trust in government. The score of zero }(0) \text { is } \\
\text { treated as a missing value and recoded as }-9\end{array}$
\end{tabular}

while low trust indicates that the government's functions and outputs do not meet the citizens' expectations or norms. ${ }^{26}$ There are at least two approaches used to measure trust in government. The first approach emphasizes people's self-identification of their trust in the government's work, or in how the government functions. The second approach emphasizes people's self-identification on their trust in the government's institutions. For example, the question is "how much of the time can you trust the police institution." ${ }^{27}$

For the purpose of practical reasons, this study only uses the second strategy. Therefore, the items of trust in government will contain people's self-identification of their trust in the government's institutions. However, the questions or the statements and the scales of answers will be adjusted and added, so that they will be more appropriate to the context of Indonesia. Thus, the questions about trust will be as follows.

\section{Political Efficacy}

Political efficacy is often defined as the feeling that people can have an impact upon the political process. Thus, efficacious individuals will feel that they can influence the political process or how the government

${ }^{26}$ Gamson, Power and Discontent, pp. 951-72.

27 Judith Torney-Purta and Wendy Klandl Richardson, "Trust in Government and Civic Engagement Among Adolescents in Australia, England, Greece, Norway, and the United States.", Conference Papers American Political Science Association Annual Meeting (2002) (Boston, MA: 2001, 2002), pp. 1-19; Paige, "Political Orientation", pp. 810-20. 
Figure 3: Indicators (Observed Variables) of Political Efficacy

\begin{tabular}{cl}
\hline Coding & \multicolumn{1}{c}{ Items/Indicators } \\
\hline Ef1 & $\begin{array}{l}\text { I consider myself well-qualified to participate in politics (even if now } \\
\text { you are not interested in participating in politics). }\end{array}$ \\
\hline Ef2 & $\begin{array}{l}\text { I think that I am as well-informed about politics and government as } \\
\text { most people. }\end{array}$ \\
\hline Ef3 & $\begin{array}{l}\text { I feel that I have a pretty good understanding of the important political } \\
\text { issues facing our country right now }\end{array}$ \\
\hline Ef4 & $\begin{array}{l}\text { Other people seem to have an easier time understanding compli cated } \\
\text { issues than I do.* }\end{array}$ \\
\hline Ef5 & $\begin{array}{l}\text { I feel that I could do as good a job as people in the government of } \\
\text { parliament. }\end{array}$ \\
\hline $\begin{array}{l}\text { Ef6 } \\
\text { I often don't feel sure of myself when talking with other people about } \\
\text { politics and government.* }\end{array}$ \\
$\begin{array}{l}\text { The answers for these statements use } 7 \text { points of the Likert scale (1=strongly } \\
\text { disagree to } 7=\text { strongly agree); and } 7 \text { indicate highest level of Efficacy (political } \\
\text { efficacy). } \\
\text { The statement with * are scored in reverse, so that the higher score indicates } \\
\text { higher efficacy. }\end{array}$
\end{tabular}

functions. ${ }^{28}$ Currently, in the literature of political science, the dimension of political efficacy developed by a sociologist, William A. Gamson, has been expanded. Efficacy is, therefore, not only a measure of beliefs about one's competence to participate or influence the political process, which is called "internal efficacy," but also beliefs about a government's responsiveness to citizens' demands, which is called "external efficacy." 29

However, for the purpose of this study, I will use the concept of efficacy proposed by Gamson based on two reasons. First, the later definition of political efficacy (internal and external) is developed in order to explain voting behavior or conventional political participation rather than more general socio-political participation. Second, the operational definition of external efficacy to some extent overlaps with the indicators of political trust used in this study. For example, one item of external efficacy is "under our form of government, the people have the final say about how the country is run, no matter who is in office;" this statement

28 Torney-Purta and Richardson, "Trust in Government".

29 Stephen C. Craig, Richard G. Niemi, and Glenn E. Silver, "Political Efficacy and Trust: A Report on the NES Pilot Study Items", Political Behavior, vol. 12, no. 3, pp. 289-314. 


\section{Munajat}

may overlap with the above indicators of trust. In addition to that, it is the Gamson's concept of political efficacy that more closely discusses the relationship between political efficacy, trust and violence. Figure 3 lists the items that are used to measure political efficacy (internal) adopted from the previous studies by Craig and Gamson. ${ }^{30}$

\section{Violent Attitude: Willingness to Employ Violence for the Ends}

The violence used in this study refers to the attitude of people towards the violent actions done some Muslim groups in Indonesia, such as violence against brothels, nightclubs, Ahmadiyah group and Shi'it community in Madura. This type of violence can be categorized under collective violence as contentious politics. ${ }^{31}$ Some also call this kind of violence simply political violence. Unlike violence in general, which is mostly random if not criminal, political violence (religious violence) is deployed for purposes like overthrowing a tyrannical regime and redefining social justice and equity. ${ }^{32}$ Therefore, most of the time, political violence is justified by the perpetrators' group.

This technique is being used because it is not feasible to measure a violent behavior, such as asking people about their involvement in political violence, the present study will only measure violent attitudes. It measures how the Muslim activists (FPI, Muhammadiyah and Nahdlatul Ulama) justify the use of violent means for the socio-political or religious ends, as can be seen in Figure 4. The complete hypothesized model for these indicators of the variables of fundamentalism, trust in government, political efficacy and willingness to employ violence (violence) can be seen in Appendix 1.

\section{Modeling Religious Violence}

Based on the hypothesized model (Appendix 1), the data was estimated using Mplus software and the result can be summarized and interpreted as follows (the result can also be seen in Appendix 2). Using LMS (Latent Moderated Structural) approach (or XWITH in Mplus), the

${ }^{30}$ Craig, Niemi, and Silver, "Political Efficacy and Trust"; Gamson, Power and Discontent, p. 42.

${ }^{31}$ Charles Tilly, The Politics of Collective Violence (Cambridge: Cambridge University Press, 2003), pp. 3, 26.

32 David E. Apter, "Political Violence in Analytical Perspective", in The Legitimization of Violence, ed. by David E. Apter (Palgrave Macmillan UK, 1997), pp. $11-23.1997$ 
Figure 4 Indicators (Observed Variables) of Violent Attitudes

\begin{tabular}{cl}
\hline Coding & \multicolumn{1}{c}{ Items/Indicators } \\
\hline V1 & $\begin{array}{l}\text { The Gay and Lesbian groups have publicly tried to conduct some } \\
\text { activities like seminars and beauty contest for gay people. Therefore, } \\
\text { it is normal for society to use force or any violent means in order to } \\
\text { stop their activities. }\end{array}$ \\
\hline V2 & $\begin{array}{l}\text { Any Muslims who bluntly declare that there is a prophet after } \\
\text { Muhammad are considered to be infidels / apostates and the enemy of } \\
\text { Islam; their blood is allowed to be shed. }\end{array}$ \\
\hline V3 & $\begin{array}{l}\text { There have been some churches built without legal consent. Therefore, } \\
\text { it is okay if some people force those churches to close, including with } \\
\text { some necessary violent means. }\end{array}$ \\
\hline V4 & $\begin{array}{l}\text { Prostitution has been legalized and localized in many cities. We have } \\
\text { no other way out to stop prostitutions, but to stop them with the use } \\
\text { of force, including some necessary violent actions. }\end{array}$ \\
\hline V5 & $\begin{array}{l}\text { The problems of gambling and drinking have been growing in } \\
\text { Indonesian society. We have no other way out to stop them except with } \\
\text { the use of force, including some necessary violent actions }\end{array}$ \\
\hline Note: The answers for these statements use 7 points of the Likert scale (1=strongly \\
(Violence).
\end{tabular}

model was estimated in two steps in order to evaluate the goodness of fit. First, the model was estimated without including the latent interactions (trust-efficacy and fundamentalism-group) or the dashed paths. The analysis with maximum likelihood (ML) estimation converged to an admissible solution. Values of the selected fit indexes for this model are Akaike (AIC) $=30909.695$, Chi-square or $\chi^{2}(475)=1093.353$ with $p<0.000$, RMSEA $=0.062$ (fair fit), CFI $=0.912$ (fair fit), and SRMR $=0.080$ (fair fit).

The high value of Chi-square, which is not desired, may indicate that the hypothesized model and observed covariances are statistically difference with $p<0.000$. However, the Chi-square is overly sensitive to sample size and multivariate deviations of normality; in fact, the sample size of 343 in this study is relatively high, which is larger than 200. Therefore, this study renders the chi-square value less important for evaluation of model fit. Instead, this study uses RMSEA, CFI and SRMR values to evaluate the model; they indicate that the hypothesized model and observed covariances are about the same.

Second, the full model (with the interactions) was estimated. The result of the second estimation did not produce Chi-square, RMSEA and Al-Jämi'ah, Vol. 53, No. 2, 2015 M/1437 H 


\section{Munajat}

CFI. Instead it reported the Akaike (AIK) value to evaluate the model. The value of AIC is 30862.417. This value is smaller than the value in the previous model by 47.278 (30909.695 - 30862.417). As it is commonly accepted, the model with the smaller Akaike (AIC) is considered as a better model. Therefore, the second model with interactions (the model in Appendix 1 or Model 2 in Appendix 2) is better than the model without interactions (Model 1 in Appendix 2).

In addition, Appendix 2 shows that the estimations of Model 1 and Model 2 are almost similar, or their parameter estimates are stable in that their factor loadings, path coefficients and $p$-values are relatively the same. Those indicate that the estimations are good and consistent. However, Model 2 may give more precise parameter estimates than that of Model 1 since it gives a lower AIC value. Therefore, the following interpretations and the hypothesis analyses are based on Model 2.

In Appendix 2, Model 2 shows that most observed variables measure their four latent variables very well. First, all the factor loadings of fundamentalism are statistically significant. For example, the coefficient of Fundamentalism $\rightarrow$ F4 (.838) can be interpreted that holding other variables constant, with every one unit increase in the latent variable of fundamentalism, the value of F3 will increase about .838 units, and it is statistically significant with $p<.000$. Second, all the factor loadings of Trust in Government are also statistically significant. For example, the coefficient of Trust $\rightarrow$ T7 (1.441) tells that holding other variables constant, with every one unit increase in Trust, the score of T7 will increase about 1.441 units.

Third, four of five factor loadings of Efficacy (political efficacy) are statistically significant. Only one of them, namely item Ef4, is not statistically significant, which means that item Ef4 is different from the other items measuring Efficacy, or it does not measure the latent variable of political efficacy. Lastly, all factor loadings of Violence (violent attitudes) are statistically significant. For example, the coefficient of Violence $\rightarrow$ V4 (.956) tells that holding other variables constant, with one unit increase in the latent variable of Violence, the V4 will increase by .956 units. It is statistically significant with $p<.000$.

As for the relationships between Violence (violent attitudes) and other variables, Model 2 (in Appendix 2) shows that Fundamentalism and Fungroup (latent interaction of Fundamentaslim and Group) are significantly associated with Violence. However, Trust, Efficacy and Efftrust (latent interaction of Efficacy and Trust) are not significantly 
associated with Violence. Additionally, the group's differences in the latent variable of Fundamentalism, Trust and Violence vary inconsistently between FPI and the nonviolent groups. The coefficients of these relationships are interpreted as follows.

The coefficient of 1.053 (Fundamentalism $\rightarrow$ Violence) tells that, holding other variables constant, with every one unit increase in Fundamentalism, Violence will increase about 1.053 units. It is statistically significant with $p<.000$. The coefficient of 1.61 (Group $\rightarrow$ Violence) tells that holding other variables constant, FPI will have a higher mean of about 1.61 units for Violence than that of the nonviolent groups. It is statistically significant with $p<.000$. The coefficient of the interaction between latent variable Fundamentalism and Group (or Fungroup) is statistically significant with a path coefficient of -.918. It cannot be directly interpreted. Therefore, the coefficient of -.918 should be put in the formula as follows:

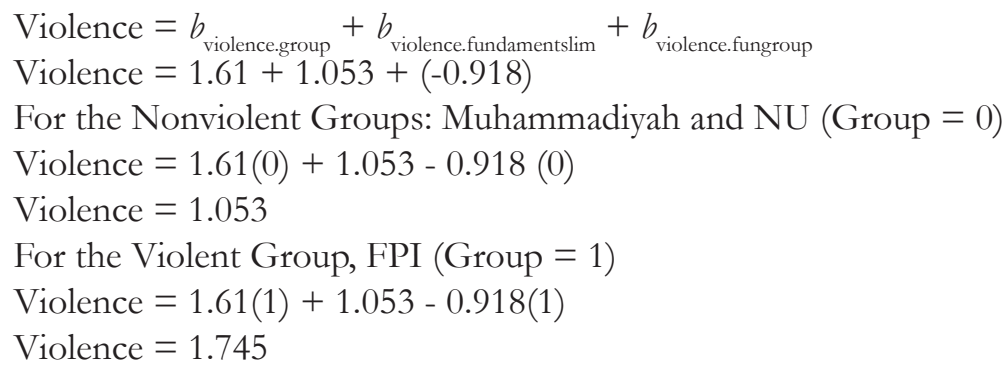

Thus, this significant interaction effect indicates that, holding other variables constant, the more fundamentalist people are, the more likely they are to have violent attitude. However, this relationship is moderated by Group, which means that FPI has steeper slope than that of the nonviolent groups (the slope for the nonviolent groups $=1.053$ and FPI $=1.74$ ), or in other words, fundamentalism for the activists of FPI has a stronger effect on violence than that for the activists of Muhammadiyah and NU.

The coefficient of .592 (Trust $\rightarrow$ Violence), .072 (Efficacy $\rightarrow$ Violence) and .183 (Efftrust $\rightarrow$ Violence) are statistically insignificant. The first two values tell that trust in government (Trust) and political efficacies (Efficacy) are not associated with violent attitudes (Violence). Similarly, the insignificant interaction between Efficacy and Trust (or Efftrust) also tells that a person who has low trust in government and higher political efficacy is not likely to be more violent.

In relation to the differences between FPI and the nonviolent Al-jāmíah, Vol. 53, No. 2, 2015 M/1437 H 


\section{Munajat}

groups in the latent variables Fundamentalism, Trust and Efficacy, the coefficient of 1.976 (Group $\rightarrow$ Fundamentalism) tells that FPI tends to be more fundamentalist by about 1.976 than that of the nonviolent groups. It is statistically significant with $p<.000$. The coefficient of -.036 (Group $\rightarrow$ Trust) tells that FPI is likely to have less trust in government by about .036 than that of the nonviolent groups. It is statistically significant with $p<.05$. Lastly, the coefficient of -.003 (Group $\rightarrow$ Efficacy) tells that FPI is likely to have less political efficacy than that of the nonviolent groups by about .003 but it is statistically not significant. This means that FPI and the nonviolent groups have the same level of political efficacy.

Finally, based on this result, this Hypothesized Model (Model 2) may be modified by dropping the latent variables of Trust, Efficacy and their interactions (Efftrust). As suggested by Kline, at least there are two reasons that should be fulfilled for dropping variables from the model: empirical and theoretical reasons. ${ }^{33}$ First, empirically based on the estimations in Model 1 and Model 2, the latent variable of Trust and Efficacy fail to explain the latent variable Violence (violent attitude). Second, theoretically most social movement studies suggest that social movement is about "collective challenges" and it is mostly about outside state institutions seeking to forward or halt social change. Therefore, whether or not a social movement adopts violent strategies, social movement actors will be likely to have a high political efficacy and a low trust in government. In short, the interaction between political efficacy (high) and trust in government (low) may explain only the emergence of social movements, not the adoptions of violent strategies by social movements. Then, the maximum likelihood estimation of this modified model can be seen in Appendix 2 "Model 3."

The summary of the hypothesis testing can be explained as follows:

- Hypothesis 1a (the more fundamentalist people are, the more likely they will justify violence) is supported by the data. There is a significant relationship between fundamentalism and violent attitude with a path coefficient of 1.053. This relationship indicates that people who are more fundamentalist - regardless of their religious affiliations- are more likely to justify the use of violent means.

- Hypothesis $1 \mathrm{~b}$ (the activists of the non violent group will be less likely to be fundamentalist than those of violent group) is supported by the data. There is a significant difference between FPI (coded 1)

${ }^{33}$ Rex B. Kline, Principles and Practice of Structural Equation Modeling (New York: Guilford Press, 2005).2005 
and the nonviolent groups, or Muhammadiyah acnd NU (coded 0) in fundamentalism with a coefficient of 1.976. This indicates that the activists of the violent group (FPI) are more fundamentalist than those of the nonviolent groups

- Hypothesis 1c (the relationship between fundamentalism and violence will be stronger for the activist of the violent group than those of the non violent group) is supported by the data. There is a significant interaction between latent variables fundamentalism and group on violence with a path coefficient of -.918. Computing this number in the model, the path coefficient of fundamentalism on violence for the nonviolent groups (coded 0 ) is 1.053 and the path coefficient for FPI (coded 1) is 1.745. This indicates that FPI has a steeper slope in the relationship between Fundamentalism and Violence than that of the nonviolent groups.

- Hypothesis 2a (people who have lower trust in government will be more likely to justify violence) is not supported by the data. The relationship between Trust and Violence with a path coefficient of .592 is statistically not significant. This indicates that people with lower trust in government are not more likely to justify the use of violent means.

- Hypothesis 2b (people who have low trust in government but high political efficacy will be likely to justify violence) is not supported by the data. The interaction effect between the variables Trust and Efficacy (Efftrust) with the coefficient of 0.183 is statistically not significant. This indicates that people who have low trust in government and high political efficacy will not be likely to justify the use of violent means.

- Hypothesis 2c (the activists of Muhammadiyah and NU will be likely to have a higher trust in government than those of FPI) is likely supported by the data. There is a statistically significant difference of the conditional mean of Trust between FPI and the nonviolent groups with the coefficient of -.036. This indicates that the activists of FPI will be likely to have a lower trust in government than those of the nonviolent groups. However, the difference value is very small (.036 point). This may also be interpreted that both of them have very low trust in government.

- Hypothesis $2 \mathrm{~d}$ (the activists of Muhammadiyah and NU will be likely to have a lower political efficacy than those of FPI) is not supported by the data. The relationship between the observed variable Group and Al-Jāmi‘ah, Vol. 53, No. 2, 2015 M/1437 H 
Munajat

the latent variable Trust with the coefficient of .003 is not significant. This indicates that the scores of political efficacy for the activist of FPI and the nonviolent groups are about the same.

\section{Concluding Remarks}

There are various perspectives of looking at political violence, and there is no single answer to the question of why this violence occurs. Some scholars look at the aspects of political environment, organization and actors to explain political violence. Political approach suggests that the characteristics of regimes or states are considered to be more determining of social movement's outcomes than other environmental factors, or more over the characteristics of the actors. In this light, authoritarianism or state repression is often considered to be the cause of the emergence of violent movements.

Unlike the above approach, other scholars focus on exogenous factors to explain violent movements, especially the organizational aspects of the movement. These includes culture, meaning construction, ideology of the movements. For example, many social movement scholars argue that political violence is mainly symbolic. Therefore, in analyzing violence, cultural and emotional effects are more important than the material damage caused by violence.

The present study discusses the causal analysis of religious violence based neither on political process nor organizational aspects. This mainly focus on individual aspects of the activists of the movements. By using a quantitative (structural equation modeling) approach, the study tests the association between dependent variable of violence (justification on the use of violent means) and independent variables: fundamentalism, trust in government, political efficacy and latent interaction of trust and efficacy. The relationship between violence and fundamentalism is also controlled by the variable of group (the group that was often considered to be violent and nonviolent).

The result of the study confirms that fundamentalism is positively associated with violence (justification on the use of violent means). Even though, this association clearly depicts that the activists of FPI have a stronger association in the relationship between fundamentalism and violence than those of the nonviolent groups (Muhammadiyah and $\mathrm{NU}$ ), the positive relationship between fundamentalism and violence is statistically obvious regardless of their group affiliation. 
On the other hand, this study does not support the argument regarding a relationship between trust in government and violence. This is because most of respondents have very low trust in government but at the same time they vary in their tendency on the use of violent means. This means that both respondents, who are violent (FPI) and not violent (the nonviolent groups), have low trust in government. Even though the group comparison on the latent variable of Trust between FPI and the nonviolent groups is statistically significant, this study contends that they have very low trust in government. The scores of both groups are concentrated in the range of one (never) and two (rarely), where FPI scores lie in the lower range and the nonviolent groups' score lie in the upper range.

In short, in the context of social movements, trust does not relate to movements' adoption of violence. This may be because by definition a social movement is a challenger of authority, and therefore, activists in social movements, whether they adopt violent means or not, should have low trust in government.

Similarly, the latent interaction between trust and political efficacy is not supported by the data. This means that the respondents who have low trust in government and high political efficacy does not necessarily means that they will be likely to justify the use of violent means. Both the activists of the violent group (FPI) and the activists of nonviolent groups have the same level of distrust in government and mid-levelspolitical efficacy.

Interestingly, only the latent variable fundamentalism sheds light on the causal model of violence. This confirms that religion (type of religiosity) influences the way people think and act. Religion contains values and rules; it determines which one is wrong and right, ethical and non-ethical, and who are friends and enemies; finally it potentially shapes the way people behave and act. In relation to this case, it can be said that types of religiosity, such as fundamentalism, moderation and liberalism, of the activists shape the dynamics of religious social movements, especially the strategy (violence or nonviolence) that they adopt to pursue their goals. As result, this study suggests that fundamentalism, a type of religiosity, can be a seed of religious violence. Therefore, understanding fundamentalism is important in designing a strategy of deterring religious violence, or any forms of radicalism and extremism.

Last but not least, the result of the study appears to contradict the arguments of Bruinessen, Jahroni and Al-Zastrouw who argue Al-Jämi‘ah, Vol. 53, No. 2, 2015 M/1437 H 
Munajat

that fundamentalism is not associated with violence and radicalism. This different argument may stems from the different approach and concept being used in defining fundamentalism, or interpretation on the operational concept of fundamentalism. This study strictly implements the operational concept from Frey, ${ }^{34}$ which emphasizes not only the aspect of belief but also the manifestation of belief in social and political lives (observed variables to measure scale of fundamentaslim). In addition, this study employs a quantitative approach, which strictly applies quantitative rules in the analysis of the relationship between violence and fundamentalism, such as the concept of "ceteris paribus" or holding other independent variables or factors constant. On the other hand, other studies, which disagree with the relationship between fundamentalism and violence, use a broader concept of fundamentalism (than those being used in the current study) and employ a qualitative approach.

34 Frey, Fundamentalism, 


\section{BIBLIOGRAPHY}

Almeida, Paul, Waves of Protest: Popular Struggle in El Salvador, 1925-2005, Minneapolis: University of Minnesota Press, 2008.

Almond, Gabriel A., R. Scott Appleby, and Emmanuel Sivan, Strong Religion: The Rise of Fundamentalism Around The World, Chicago: University of Chicago Press, 2003.

Altemeyer, Bob and Bruce Hunsberger, "Authoritarianism, Religious Fundamentalism, Quest, and Prejudice", The International Journal for the Psychology of Religion, vol. 2, no. 2, 1992, pp. 113-33 [http:// dx.doi.org/10.1207/s15327582ijpr0202_5].

----, "Research: A Revised Religious Fundamentalism Scale: The Short and Sweet of It", The International Journal for the Psychology of Religion, vol. 14, no. 1, 2004, pp. 47-54 [http://dx.doi.org/10.1207/ s15327582ijpr1401_4].

Apter, David E., "Political Violence in Analytical Perspective", in The Legitimization of Violence, ed. by David E. Apter, Palgrave Macmillan UK, 1997, pp. 1-32.

Conteh-Morgan, Earl, Collective Political Violence: An Introduction to the Theories and Cases of Violent Conflicts, New York: Routledge, 2004.

Craig, Stephen C., Richard G. Niemi, and Glenn E. Silver, "Political Efficacy and Trust: A Report on the NES Pilot Study Items", Political Behavior, vol. 12, no. 3, pp. 289-314 [http://dx.doi.org/10.1007/ BF00992337].

Ekkart, Zimmermann, Political Violence, Crises, and Revolutions: Theories and Research, vol. 79, Boston, Mass: G. K. Hall, 1985.

Frey, Rebecca Joyce, Fundamentalism, New York: Facts On File, 2007.

Gamson, William A., Power and Discontent, Homewood: Dorsey Press, 1968.

Herbert W. Marsh, Zhonglin Wen, and Kit-Tai Hau, “'Structural Equation Models of Latent Interaction and Quadratic Effects"', in Structural Equation Modeling: A Second Course, ed. by Gregory R. Hancock and Ralph O. Mueller, IAP, 2006.

Jahroni, Jajang, Defending the Majesty of Islam: Indonesia's Front Pembela Islam, 1998-2003, Chiang May, Thailand: Silkworm Books, 2008.

Juergensmeyer, Mark, Terror in the Mind of God: The Global Rise of Religious 
Munajat

Violence, Berkeley: University of California Press, 2003.

Klein, Andreas and Helfried Moosbrugger, "Maximum Likelihood Estimation of Latent Interaction Effects with the LMS Method", Psychometrika, vol. 65, no. 4, pp. 457-74 [http://dx.doi.org/10.1007/ BF02296338].

Kline, Rex B., Principles and Practice of Structural Equation Modeling, New York: Guilford Press, 2005.

Kornhauser, William, The Politics of Mass Society, Glencoe: Free Press, 1959.

Marty, Martin E. and R. Scott Appleby, "Introduction: A Sacred Cosmos, Scandalous Code, Defiant Society", in Fundamentalisms and Society: Reclaiming the Sciences, the Family, and Education, ed. by Martin E. Marty and R. Scott Appleby, Chicago: University of Chicago Press, 1993.

McAdam, Doug, Political Process and the Development of Black Insurgency, 1930-1970, Chicago: University of Chicago Press, 1982.

Miller, Arthur H., "Political Issues and Trust in Government: 19641970*”, American Political Science Review, vol. 68, no. 3, 1974, pp. 951-72 [http://dx.doi.org/10.2307/1959140].

Moaddel, Mansoor and Stuart A. Karabenick, "Religious Fundamentalism Among Young Muslims in Egypt and Saudi Arabia", Social Forces, vol. 86, no. 4, 2008, pp. 1675-710 [http://dx.doi.org/10.1353/ sof.0.0059].

Muthén, Linda K. and Bengt O. Muthén, Mplus Statistical Analysis with Latent Variables: User's Guide, Los Angeles: Muthén \& Muthén, 2010.

$\mathrm{Ng}$, Al-Zastrouw, Gerakan Islam Simbolik: Politik Kepentingan FPI, Yogyakarta: LKiS, 2006.

Numrich, Paul D., "Fundamentalisms and American Pluralism", Journal of Ecumenical Studies, vol. 42, no. 1, 2007, p. 9.

Paige, Jeffery M., "Political Orientation and Riot Participation", American Sociological Review, vol. 36, no. 5, 1971, pp. 810-20 [http://dx.doi. org $/ 10.2307 / 2093668]$.

Porta, Donatella Della, "Research on Social Movements and Political Violence", Qualitative Sociology, vol. 31, no. 3, 2008, pp. 221-30 [http://dx.doi.org/10.1007/s11133-008-9109-x].

Ransford, H. Edward, "Isolation, Powerlessness, and Violence: A Study of Attitudes and Participation in the Watts Riot", American Journal of Sociology, vol. 73, no. 5, 1968, pp. 581-91 [http://dx.doi. 
org/10.1086/224532].

Rothschild, Zachary K., Abdolhossein Abdollahi, and Tom Pyszczynski, "Does Peace Have a Prayer? The Effect of Mortality Salience, Compassionate Values, and Religious Fundamentalism on Hostility toward Out-groups", Journal of Experimental Social Psychology, vol. 45, no. 4, 2009, pp. 816-27 [http://dx.doi.org/10.1016/j. jesp.2009.05.016].

Samuel B. Green and Marilyn S. Thomson, "Evaluating Between-Group Differences in Latent Variable Means", in Structural Equation Modeling: A Second Course, ed. by Gregory R. Hancock and Ralph O. Mueller, Connecticut: Information Age Publishing, 2006.

Shortell, Timothy, "Radicalization of Religious Discourse in El Salvador: The Case of Oscar A. Romero", Sociology of Religion, vol. 62, no. 1, 2001, pp. 87-103 [http://dx.doi.org/10.2307/3712232].

Steinhoff, Patricia and Gilda Zwerman, "Introduction to the Special Issue on Political Violence", Qualitative Sociology, vol. 31, no. 3, 2008, pp. 213-20 [http://dx.doi.org/10.1007/s11133-008-9111-3].

Tilly, Charles, The Politics of Collective Violence, Cambridge: Cambridge University Press, 2003.

Torney-Purta, Judith and Wendy Klandl Richardson, "Trust in Government and Civic Engagement Among Adolescents in Australia, England, Greece, Norway, and the United States.", Conference Papers American Political Science Association Annual Meeting (2002), Boston, MA: 2001, 2002.

Wiktorowicz, Quintan, "Introduction: Islamic Activism, a Social Movement Theory", in Islamic Activism, a Social Movement Theory Approach, ed. by Quintan Wiktorowicz, Bloomington Indiana: Indiana University Press, 2004. 
Munajat

Appendix 1 Hypothesized Model

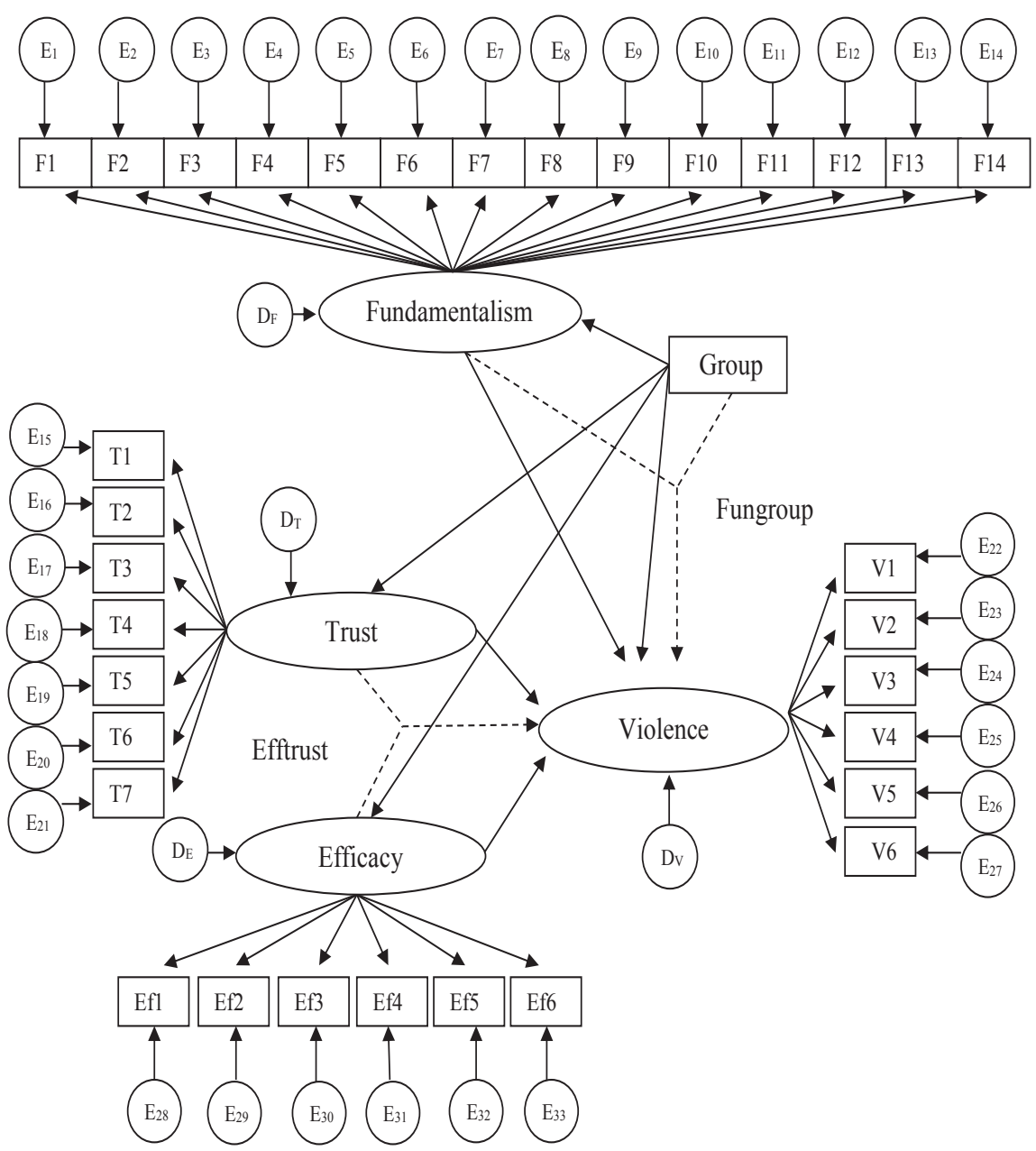

Note: rectangle $=$ observed variable, oval $=$ latent variable, and circle $=$ error terms $(\mathrm{E}$ and $\mathrm{D})$

The dashed lines are the interaction between two variables

Fungroup is the interaction between Fundamentalism and Group and Efftrust is the latent interaction between Efficacy and Trust 
Appendix 2: Maximum likelihood Parameter Estimates of the Models

\begin{tabular}{|c|c|c|c|c|c|c|}
\hline \multirow[b]{2}{*}{ Parameter } & \multicolumn{2}{|c|}{ Model 1} & \multicolumn{2}{|c|}{ Model 2} & \multicolumn{2}{|c|}{ Model 3} \\
\hline & Estimate & SE & Estimate & SE & Estimate & SE \\
\hline Fundamentalism $\rightarrow$ F1 & $1^{\text {a }}$ & 0 & $1^{\text {a }}$ & 0 & $1^{\mathrm{a}}$ & 0 \\
\hline Fundamentalism $\rightarrow$ F2 & 0.79 *** & 0.054 & $0.785^{* * * *}$ & 0.042 & $0.785^{* * *}$ & 0.043 \\
\hline Fundamentalism $\rightarrow$ F3 & $0.922^{* * * *}$ & 0.089 & $0.905^{* * *}$ & 0.088 & $0.896^{* * *}$ & 0.087 \\
\hline Fundamentalism $\rightarrow$ F4 & $0.822^{* * * *}$ & 0.081 & $0.838^{* * * *}$ & 0.088 & $0.831^{* * *}$ & 0.087 \\
\hline Fundamentalism $\rightarrow$ F5 & $0.268^{* * *}$ & 0.054 & $0.277^{* * * *}$ & 0.073 & $0.271^{* * *}$ & 0.072 \\
\hline Fundamentalism $\rightarrow$ F6 & $0.308^{* * * *}$ & 0.042 & $0.315^{* * *}$ & 0.053 & $0.316^{* * *}$ & 0.053 \\
\hline Fundamentalism $\rightarrow$ F7 & $0.377^{* * * *}$ & 0.049 & $0.372^{* * * *}$ & 0.057 & $0.375^{* * *}$ & 0.058 \\
\hline Fundamentalism $\rightarrow$ F8 & $1.117^{* * *}$ & 0.075 & $1.116^{* * * *}$ & 0.055 & $1.124^{* * * *}$ & 0.056 \\
\hline Fundamentalism $\rightarrow$ F9 & $0.957^{* * * *}$ & 0.071 & $0.964^{* * * *}$ & 0.058 & $0.968^{* * *}$ & 0.059 \\
\hline Fundamentalism $\rightarrow$ F10 & $1.14 * * *$ & 0.072 & $1.139 * * *$ & 0.056 & $1.147^{* * *}$ & 0.057 \\
\hline Fundamentalism $\rightarrow$ F11 & $0.897^{* * * *}$ & 0.078 & $0.905^{* * *}$ & 0.068 & $0.91^{* * * *}$ & 0.069 \\
\hline Fundamentalism $\rightarrow$ F12 & $0.793^{* * * *}$ & 0.064 & $0.796^{* * * *}$ & 0.057 & $0.8^{* * *}$ & 0.057 \\
\hline Fundamentalism $\rightarrow$ F13 & $0.697 * * *$ & 0.065 & $0.698^{* * * *}$ & 0.072 & $0.702^{* * *}$ & 0.073 \\
\hline Fundamentalism $\rightarrow$ F14 & $0.967^{* * * *}$ & 0.067 & $0.959 * * *$ & 0.054 & $0.962^{* * * *}$ & 0.054 \\
\hline Trust $\rightarrow \mathrm{T} 1$ & $1^{\text {a }}$ & 0 & $1^{\text {a }}$ & 0 & - & - \\
\hline Trust $\rightarrow \mathrm{T} 2$ & $2.809^{* *}$ & 1.007 & $2.613^{* *}$ & 0.889 & - & - \\
\hline Trust $\rightarrow \mathrm{T} 3$ & $2.998^{* *}$ & 1.075 & $2.78^{* *}$ & 0.996 & - & - \\
\hline Trust $\rightarrow$ T4 & $5.053 *$ & 1.983 & $4.63^{* * *}$ & 1.715 & - & - \\
\hline Trust $\rightarrow$ T5 & $7.114^{*}$ & 2.808 & $6.54^{* * *}$ & 2.327 & - & - \\
\hline Trust $\rightarrow$ T6 & $6.9 *$ & 2.733 & $6.287^{* *}$ & 2.34 & - & - \\
\hline Trust $\rightarrow \mathrm{T} 7$ & $1.567 *$ & 0.654 & $1.441 *$ & 0.593 & - & - \\
\hline Efficacy $\rightarrow$ Ef1 & $1^{\text {a }}$ & 0 & $1^{\mathrm{a}}$ & 0 & - & - \\
\hline Efficacy $\rightarrow$ Ef2 & $0.597 * * *$ & 0.061 & $0.6^{* * * *}$ & 0.072 & - & - \\
\hline Efficacy $\rightarrow$ Ef3 & $0.587 * * *$ & 0.056 & 0.59 *** & 0.06 & - & - \\
\hline Efficacy $\rightarrow$ Ef4 & 0.076 & 0.06 & 0.078 & 0.076 & - & - \\
\hline Efficacy $\rightarrow$ Ef5 & $0.894^{* * * *}$ & 0.074 & $0.9 * * *$ & 0.085 & - & - \\
\hline Efficacy $\rightarrow$ Ef6 & $0.376^{* * * *}$ & 0.067 & $0.378^{* * * *}$ & 0.078 & - & - \\
\hline Violence $\rightarrow \mathrm{V} 1$ & $1^{\mathrm{a}}$ & 0 & $1^{\mathrm{a}}$ & 0 & $1^{\mathrm{a}}$ & 0 \\
\hline Violence $\rightarrow$ V2 & $0.983^{* * * *}$ & 0.056 & $0.983^{* * * *}$ & 0.049 & $0.988^{* * * *}$ & 0.046 \\
\hline Violence $\rightarrow$ V3 & $0.876^{* * * *}$ & 0.048 & $0.873^{* * * *}$ & 0.044 & $0.881^{* * *}$ & 0.042 \\
\hline Violence $\rightarrow$ V4 & $0.941^{* * *} *$ & 0.047 & $0.956^{* * *}$ & 0.041 & $1.007^{* * * *}$ & 0.039 \\
\hline Violence $\rightarrow$ V5 & $0.893^{* * * *}$ & 0.049 & $0.91^{* * * *}$ & 0.052 & $0.984 * * *$ & 0.054 \\
\hline Violence $\rightarrow$ V 6 & $0.849^{* * * *}$ & 0.055 & $0.879^{* * * *}$ & 0.06 & $1.079^{* * *}$ & 0.047 \\
\hline Fundamentalism $\rightarrow$ Violence & $0.803^{* * * *}$ & 0.072 & $1.053^{* * * *}$ & 0.095 & $0.979 * * *$ & 0.095 \\
\hline Trust $\rightarrow$ Violence & -1.62 & 1.042 & 0.592 & 0.942 & - & - \\
\hline Efficacy $\rightarrow$ Violence & 0.089 & 0.049 & 0.072 & 0.058 & - & - \\
\hline Fungroup $\rightarrow$ Violence & - & - & $-0.918^{* * * *}$ & 0.127 & $-0.893 * * *$ & 0.095 \\
\hline Efftrust $\rightarrow$ Violence & - & - & 0.183 & 0.934 & - & - \\
\hline Group $\rightarrow$ Fundamentalism & $1.973^{* * *}$ & 0.167 & $1.976^{* * *}$ & 0.149 & $1.963^{* * *}$ & 0.149 \\
\hline Group $\rightarrow$ Trust & $-0.032 *$ & 0.016 & $-0.036^{*}$ & 0.018 & - & - \\
\hline Group $\rightarrow$ Efficacy & -0.005 & 0.162 & -0.003 & 0.158 & - & - \\
\hline Group $\rightarrow$ Violence & 0.227 & 0.165 & 1.61 *** & 0.198 & $1.717^{* * *}$ & 0.129 \\
\hline
\end{tabular}

Note: Model 1: hypothesized model without interactions, Model 2: full hypothesized model, and Model 3: modified model.

Fungroup is the interaction between Fundamentalism and Group.

Efftrust is the interaction between Efficacy and Trust.

${ }^{a}$ Not tested for significance; ${ }^{*} \mathrm{p}<.05 \quad{ }^{* *} \mathrm{p}<.01 \quad{ }^{* * *} \mathrm{p}<.001$ (two-tailed tests) 